Aspirasi: Jurnal Masalah-Masalah Sosial | Volume 10, No. 2 Desember 2019

ISSN: 2086-6305 (print) ISSN: 2614-5863 (electronic)

DOI: https://doi.org/10.22212/aspirasi.v10i2.1161

link online: http://jurnal.dpr.go.id/index.php/aspirasi/index

\title{
Pembangunan Sosial oleh Paguyuban Jamu Gendong Lestari melalui Sektor Ekonomi Kreatif
}

\author{
Social Development by Paguyuban Jamu Gendong Lestari \\ through the Creative Economy Sector \\ Asri Christiyani \\ asri.christiyani@gmail.com \\ Penerima Beasiswa Unggulan Kementerian Pendidikan Dan Kebudayaan \\ Pascasarjana Ilmu Kesejahteraan Sosial \\ Fakultas Ilmu Sosial Ilmu Politik Universitas Indonesia \\ Jl. Prof. Dr. Selo Soemardjan, Pondok Cina, Beji, Kota Depok, Jawa Barat
}

Naskah diterima: 28 September 2019 | Naskah direvisi: 7 November 2019 | Naskah diterbitkan: 29 Desember 2019

\begin{abstract}
This article discusses social development by the community carried out by Paguyuban Jamu Gendong Lestari in Kuningan Barat Village, Mampang Prapatan Subdistrict, South Jakarta through the creative economy sector, namely jamu gendong business as a culinary sub-sector based on culture and local wisdom. This study uses a qualitative approach with descriptive types. The results show that the Paguyuban Jamu Gendong Lestari as a community that runs a business in the creative economy, namely jamu as an Indonesian cultural heritage has succeeded in carrying out the social development process based on seven characteristics of social development. The social development strategy that is carried out is a social development strategy by the community through which the members of the Paguyuban Jamu Gendong Lestari are members who work together harmoniously to meet their needs, solve their problems and try to create opportunities to improve lives through the management of jamu businesses.
\end{abstract}

Keywords: social development, social welfare, creative economy, jamu

\begin{abstract}
Abstrak: Artikel ini membahas mengenai pembangunan sosial oleh masyarakat yang dilakukan oleh Paguyuban Jamu Gendong Lestari di Kelurahan Kuningan Barat Kecamatan Mampang Prapatan Jakarta Selatan melalui budaya dan kearifan lokal. Penelitian ini menggunakan pendekatan kualitatif dengan jenis deskriptif. Hasil menunjukkan bahwa Paguyuban Jamu Gendong Lestari sebagai komunitas yang menjalankan usaha di bidang ekonomi kreatif yaitu jamu sebagai warisan budaya Indonesia telah berhasil melakukan proses pembangunan sosial berdasarkan tujuh karakteristik pembangunan sosial. Strategi pembangunan sosial yang dijalankan adalah strategi pembangunan sosial oleh masyarakat melalui wadah Paguyuban Jamu Gendong Lestari. Masyarakat yang menjadi anggota saling bekerja sama secara harmonis untuk memenuhi kebutuhan mereka, memecahkan masalah mereka dan berupaya menciptakan kesempatan guna memperbaiki hidup melalui pengelolaan usaha jamu gendong.
\end{abstract}

Kata kunci: pembangunan sosial, kesejahteraan sosial, ekonomi kreatif, jamu 


\section{Pendahuluan}

Sidang Umum Perserikatan Bangsa Bangsa (PBB) ke-70 pada bulan September 2015 di New York, Amerika Serikat menjadi titik sejarah baru dalam pembangunan global. Sebanyak 193 kepala negara dan pemerintahan dunia hadir untuk menyepakati agenda pembangunan universal baru yang bernama Sustainable Development Goals (SDGs) atau komitmen Tujuan Pembangunan Berkelanjutan yang berisi 17 tujuan dan 169 sasaran yang berlaku mulai tahun 2016 sampai dengan tahun 2030. SDGs merupakan kelanjutan Millennium Development Goals (MDGs) yang telah berakhir pada tahun 2015.

SDGs disebut sebagai agenda pembangunan global yang cakupannya lebih luas dan inklusif daripada MDGs. Berbeda dengan MDGs yang penyusunannya bersifat eksekutif sebagai ramuan para pakar negara-negara anggota Organisation for Economic Cooperation and Development (OECD) dan beberapa lembaga internasional, SDGs melibatkan pemangku kepentingan yang cakupannya lebih luas. Sejak awal penyusunan SDGs dibuat melalui proses partisipatoris dan sangat inklusif dengan cara konsultasi langsung dengan semua kalangan yang meliputi pemerintah, masyarakat sipil, akademisi dan pihak swasta baik dari negara maju maupun berkembang, sebagaimana dijelaskan dalam dokumen United Nations berjudul Transforming Our World: The 2030 Agenda for Sustainable Development. Dokumen menyebutkan bahwa:

"The goals and targets are the result of over two years of intensive public consultation and engagement with civil society and other stakeholders around the world, which paid particular attention to the voices of the poorest and most vulnerable. This consultation included valuable work done by the Open Working Group of the General Assembly on Sustainable Development Goals and by the United Nations, whose Secretary General provided a synthesis report in December 2014." (United Nations, 2015: 3)

Baik di tingkat global dan nasional, isu mengenai kemiskinan masih menjadi isu sentral dalamagenda SDGs, di mana upaya mengentaskan segala bentuk kemiskinan merupakan tujuan pertama agenda SDGs. Indonesia berkomitmen serius dalam melaksanakan SDGs yaitu dengan ditetapkannya Peraturan Presiden Republik Indonesia Nomor 59 Tahun 2017 tentang Pelaksanaan Pencapaian Tujuan Berkelanjutan di mana tujuan dan targetnya dikelompokan ke dalam empat pilar yaitu pilar pembangunan sosial, pilar pembangunan ekonomi, pilar pembangunan lingkungan dan pilar pembangunan hukum dan tata kelola.

Menurut press release Badan Pusat Statistik pada bulan Maret 2018, jumlah penduduk miskin (penduduk dengan pengeluaran per kapita per bulan di bawah Garis Kemiskinan) di Indonesia mencapai 25,95 juta orang $(9,82 \%)$ yang belum melampaui target sasaran nasional yang tercantum dalam Rencana Pembangunan Jangka Menengah Nasional 2015-2019 yaitu sebesar 7-8\% (BPS,2018: 1). Oleh karena itu masih harus dilakukan upaya yang serius dalam mengatasi permasalahan kemiskinan tersebut.

Keberhasilan suatu negara mengatasi kemiskinan pada hakikatnya tidak terlepas dari adanya sinergi antara pemerintah, pihak swasta, dan masyarakat. Masyarakat menjadi elemen penting dalam pembangunan sehingga perlu ada peran aktif masyarakat untuk mengentaskan kemiskinan. Negara tidak sekadar mendorong pertumbuhan ekonomi saja, melainkan juga fokus pada kebijakan pengentasan kemiskinan yang berbasis partisipasi masyarakat. Langkah di atas sejalan dengan pemikiran Hollnsteiner seperti dikutip Tjokrowinoto (1995: 39) yang berpendapat perlunya model pembangunan yang mampu mempromosikan kekuatan manusia, bukan mengabadikan ketergantungan masyarakat miskin terhadap pemerintah.

Pembangunan dan upaya pengentasan kemiskinan memang tetap memerlukan intervensi negara dan pemerintah, namun perlu didorong untuk dapat membangkitkan partisipasi aktif masyarakat dalam menggali potensi, memecahkan masalah dan memenuhi kebutuhan mereka sendiri. Hal ini juga sesuai dengan pendapat Midgley yang menekankan perlunya menggunakan pendekatan pembangunan sosial dalam menanggulangi kemiskinan dan sebagai integrasi antara tujuan ekonomi dan tujuan sosial dalam pembangunan. 
"[That] social development is in other words, an approach to promoting people's welfare that is well suited not only to enhancing quality of life for all citizens but to address the problems of underdevelopment. The integration of economic and social objectives is a key element of social development." (Midgley, 2005: 7).

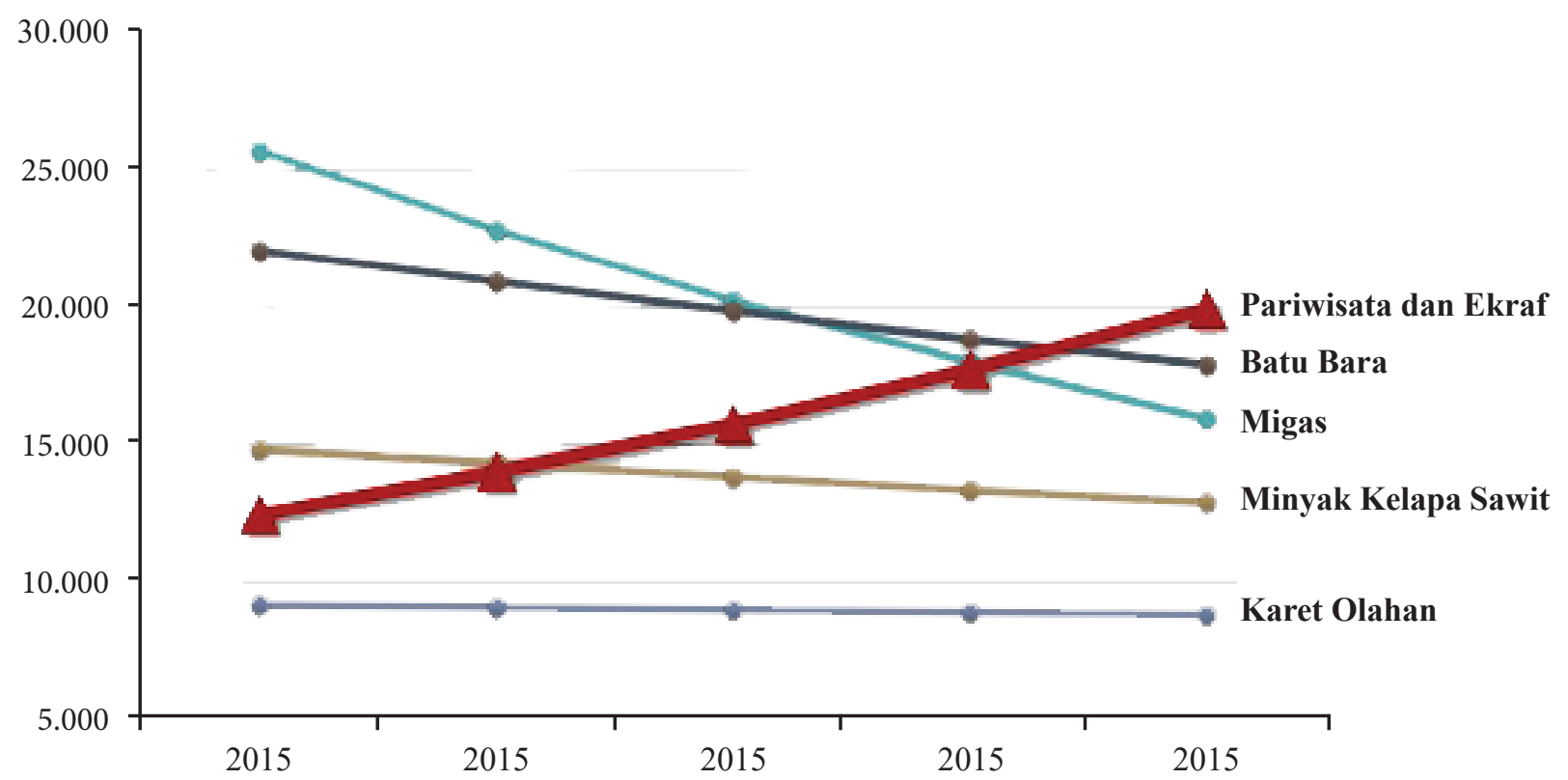

Gambar 1. Proyeksi Penerimaan Devisa Dari Sektor-Sektor Utama dalam Perekonomian Indonesia Sumber: Kemenparekraf, 2014

Pada tahun 2020, sektor pariwisata dan ekonomi kreatif di Indonesia diproyeksikan sebagai penyumbang terbesar bagi Indonesia. Proyeksi ini dapat dilihat pada Gambar 1 dengan kurva pariwisata dan ekonomi kreatif yang terus meningkat. Meningkatnya pertumbuhan ekonomi, penerimaan devisa, pemerataan pembangunan dan penyerapan tenaga kerja adalah sederetan tujuan jangka panjang yang ingin dicapai melalui pembangunan pariwisata dan ekonomi kreatif.

Sebagai komitmen serius agar pengembangan ekonomi kreatif di Indonesia semakin sistematis dan terarah, sektor ekonomi kreatif dipecah dari sektor pariwisata yaitu melalui Peraturan Presiden Nomor 72 Tahun 2015 dibentuk badan baru yang langsung bertanggung jawab kepada presiden yaitu Badan Ekonomi Kreatif yang bertugas mengembangkan kebijakan ekonomi kreatif sebagai salah satu tumpuan perekonomian di masa depan dan diharapkan dapat mendorong terwujudnya integrasi antara tujuan ekonomi dan tujuan sosial dalam pencapaian SDGs yang telah diintegrasikan dalam Rencana Pembangunan Jangka Menengah Nasional (RPJMN) 20202024.
Berdasarkan hasil survei ekonomi kreatif tahun 2016, ekonomi kreatif mampu memberikan kontribusi secara signifikanterhadap pertumbuhan ekonomi nasional. Pada tahun 2015 sektor ini menyumbang 852 triliun rupiah terhadap PDB nasional $(7,38 \%)$, menyerap 15,9 juta tenaga kerja $(13,90 \%)$, dan nilai ekspor US\$19,4 miliar (12,88\%). Di dalam Peraturan Presiden Nomor 72 Tahun 2015, produk-produk ekonomi kreatif diklasifikasikan kedalam 16 subsektor yaitu: (1) arsitektur; (2) desain interior; (3) desain komunikasi visual; (4) desain produk; (5) film, animasi dan video; (6) fotografi; (7) kriya; (8) kuliner; (9) musik; (10) fesyen; (11) aplikasi dan game developer; (12) penerbitan; (13) periklanan; (14) televisi dan radio; (15) seni pertunjukan; dan (16) seni rupa (Ditjenpp Kemenkumham, 2015). Melalui gambar berikut disajikan data kontribusi produk domestik bruto (PDB) Ekonomi Kreatif menurut subsektor.

Berdasarkan data dari Badan Ekonomi Kreatif dan Badan Pusat Statistik dalam publikasi Kontribusi PDB Ekonomi Kreatif menurut subsektor (Bekraf dan BPS, 2017: 5), di antara 16 (enam belas) subsektor ekonomi kreatif yang 


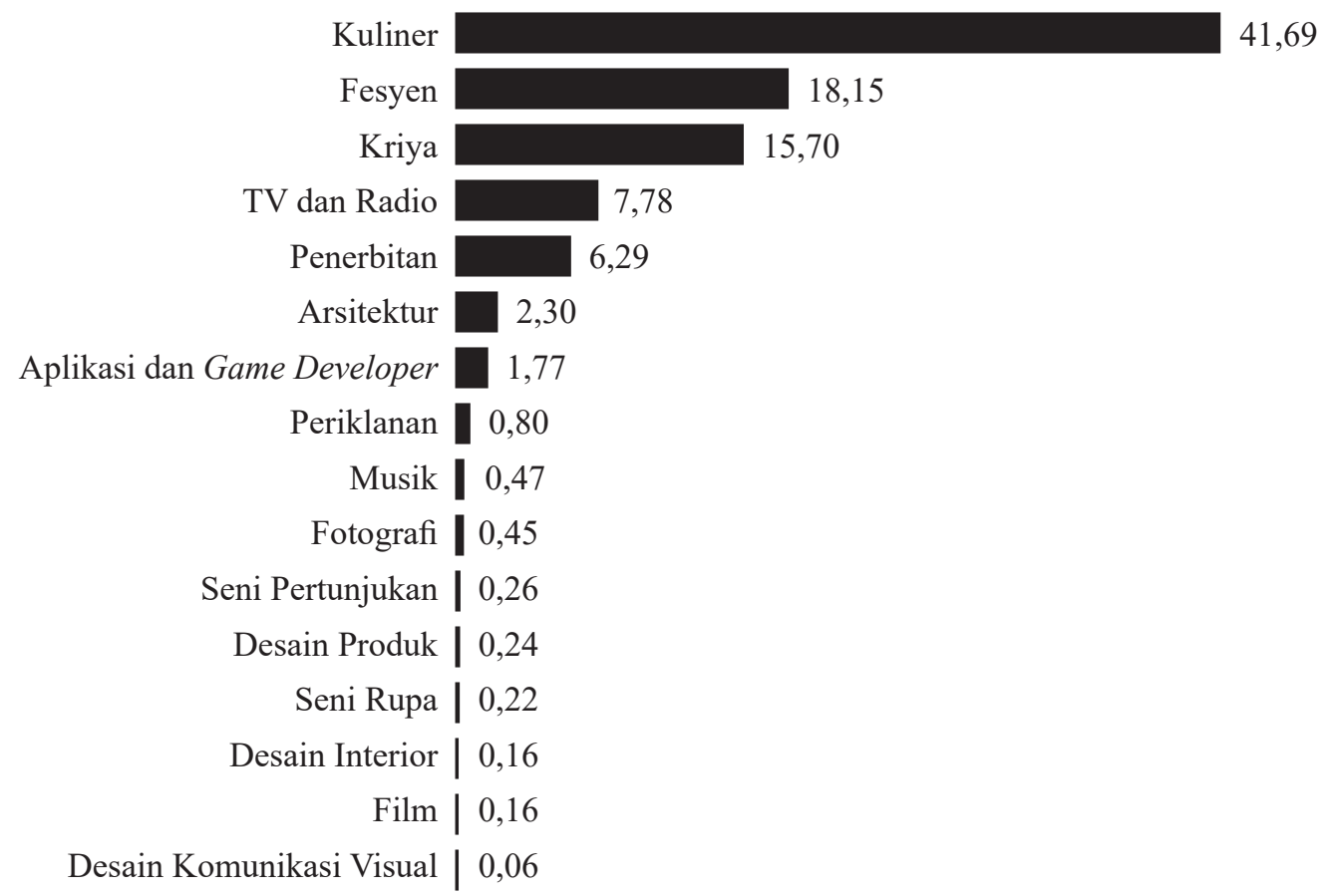

Gambar 2. Persentase Kontribusi PDB Ekonomi Kreatif Menurut Subsektor Sumber: Badan Ekonomi Kreatif dan BPS, 2017: 5

berkembang di Indonesia, subsektor kuliner memberikan kontribusi yang cukup besar, yaitu $41,69 \%$ dari total PDB ekonomi kreatif. Pertumbuhan ekonomi kreatif kuliner sangat menjanjikan, terutama di kota besar seperti DKI Jakarta yang memiliki 10.177.924 jiwa di mana $71,51 \%$ atau sebesar 7.278.316 jiwa merupakan penduduk usia produktif (Pemprov DKI Jakarta, 2018: 89).

Jakarta memberikan tempat bagi perkembangan ekosistem kreatif, baik secara individu maupun dalam komunitas. Salah satu komunitas kreatif yang tumbuh dan berkembang di Jakarta adalah Paguyuban Jamu Gendong Lestari yang menggeluti subsektor kuliner berbasis budaya dan kearifan lokal yaitu jamu. Paguyuban Jamu Gendong Lestari menarik untuk diteliti berkaitan dengan keberhasilannya dalam melakukan pembangunan sosial oleh masyarakat yang dibentuk oleh masyarakat secara mandiri.

Pangestu (2008, dalam Agung, 2015: 587) menguraikan beberapa alasan mengapa industri kreatif perlu dikembangkan di Indonesia. Alasan yang dimaksud antara lain: (1) memberikan kontibusi ekonomi yang signifikan, (2) menciptakan iklim bisnis yang positif, (3) membangun citra dan identitas bangsa, (4) berbasis kepada sumber daya yang terbarukan,
(5) menciptakan inovasi dan kreativitas yang merupakan keunggulan kompetitif suatu bangsa, (6) memberikan dampak sosial yang positif. Jamu tradisional berpotensi diberdayakan untuk meningkatkan ketahanan ekonomi masyarakat (Kartika, 2013: 649).

Lebih lanjut dijelaskan bahwa pengembangan ekonomi kreatif ini membutuhkan kreativitas masyarakat terutama keterampilan. Kreativitas tersebut berdasarkan sumber daya manusia yang berkualitas, sehingga untuk mencapai hal tersebut perlu dilakukan pemberdayaan masyarakat berbasis ekonomi kreatif. Dalam pemberdayaan ini, masyarakat diberi motivasi, pelatihan, dan pembinaan keterampilan yang bertahap sampai mandiri dan mampu memenuhi kebutuhan hidupnya secara finansial (Yulinda, 2017: 2).

Sementara itu, model pemberdayaan berbasis komunitas diperlukan sebagai wadah untuk saling mendukung dan termotivasi untuk menjadi individu yang berdaya (Yusuf \& Nimasari, 2011: 65). Pemberdayaan berbasis komunitas yang mengambil penelitian pada komunitas ibu-ibu yang menyandang status janda dan komunitas lanjut usia memberikan hasil yang positif yaitu dari segi pengetahuan dan keterampilan serta segi ekonomi dalam menambah penghasilan karena hasil kerajian dapat dijual (Patria dan 
Mutmainah, 2018: 26). Kedua penelitian tersebut menfokuskan komunitas sebagai wadah untuk melakukan aktivitas bersama sebagai peluang untuk membuat usaha yang mampu menciptakan kemandirian dan usaha yang meningkatakan taraf hidup para anggotanya.

Kesimpulan dari penelitian-penelitian di atas bahwa masyarakat masih diposisikan sebagai penerima program sehingga partisipasi rendah, memiliki ketergantungan yang besar terhadap pembuat program dan kendala keberlanjutan program. Untuk menjawab permasalahan penelitian di atas, dalam rangka memberikan sumbangan penelitian,maka dalam artikel ini akan dibahas proses pembangunan sosial yang berangkat dari masyarakat di mana pembentukannya diinisasi oleh masyarakat itu sendiri dan menggambarkan proses untuk mewujudkan kemandirian dan meningkatkan kesejahteraan di mana masyarakat yang menjadi aktor utama dalam mewujudkan pembangunan sosial.

Penelitian ini menggunakan pendekatan kualitatif dengan jenis penelitian deskriptif. Pemilihan jenis ini disebabkan karena penelitian deskriptif memberikan gambaran tentang rincian spesifik dari situasi, lingkungan sosial, atau hubungan antara pembangunan sosial dalam kegiatan ekonomi kreatif jamu gendong. Hasil dari penelitian deskriptif adalah gambaran rinci tentang subjek, yang berfokus pada gambaran tentang situasi dan fenomena sosial yang ada di lapangan.

Dengan demikian, maka tujuan dari penelitian ini antara lain menggambarkan proses pembangunan sosial oleh masyarakat yang dilakukan oleh Paguyuban Jamu Gendong Lestari melalui sektor ekonomi kreatif yaitu pengelolaan usaha jamu serta menggambarkan faktor penguat keberadaan Paguyuban Jamu Gendong Lestari yang berkaitan dengan upaya peningkatan kesejahteraan sosial dan ekonomi masyarakat. Penelitian ini diharapkan dapat mendeskripsikan proses pembangunan sosial meliputi kondisi yang akan diubah, proses perubahannya dan tujuan pembangunan sosial yang ingin dicapai serta strategi pembangunan sosial yang dijalankan dan memperkaya literatur studi yang berkaitan dengan pembangunan kesejahteraan sosial.

Penelitian dilakukan pada bulan September sampai dengan Oktober 2018. Lokasi penelitian ini bertempat di RT 08 RW 03 Kelurahan Kuningan Barat Mampang Jakarta Selatan di mana terdapat komunitas masyarakat yang menekuni usaha kuliner jamu yaitu Paguyuban Jamu Gendong Lestari. Pemilihan informan dilakukan dengan teknik purposive sampling yaitu mereka yang mengetahui dengan pasti sejarah dan perkembangan Paguyuban Jamu Gendong Lestari serta proses pembangunan sosial yang dijalankan. Informan yang dipilih untuk penelitian ini antara lain: (1) Pendiri sekaligus Ketua Paguyuban Jamu Gendong Lestari, (2) Sekretaris, (3) Koordinator Unit Usaha, (4) Anggota sebanyak 3 orang. Teknik pengumpulan data dilakukan dengan wawancara mendalam, observasi, dan studi dokumentasi.

Analisis data yang digunakan adalah analisis data kualitatif yang merupakan prosedur penelitian yang menghasilkan data deskriptif berupa ucapan atau tulisan dan perilaku orangorang yang diamati. Pendekatan kualitatif pada penelitian ini diharapkan mampu menghasilkan uraian yang mendalam tentang ucapan, tulisan, dan atau perilaku yang dapat diamati dari suatu individu, kelompok, masyarakat, dan atau organisasi tertentu dalam suatu setting konteks tertentu yang dikaji dari sudut pandang yang utuh, komprehensif, dan holistik.

Proses kegiatan analisis data dalam penelitian ini dimulai dari pengumpulan data dari sumber data berupa wawancara mendalam atau individual in-depth interview, observasi dan serta dokumentasi. Data yang telah terkumpul tersebut dibaca untuk mempelajari, dipilah-pilah baik data verbal maupun non-verbal untuk diklasifikasikan berdasarkan kategori data sehingga menemukan pola yang sesuai dengan tema kajian penelitian ini. Karena data yang diperoleh memiliki sarat makna yang dapat menjelaskan fenomena sosial yang tersembunyi di kehidupan masyarakat. Secara singkat tahapan-tahapan proses analisis data di gambarkan sebagai melalui skema gambar di bawah ini: 


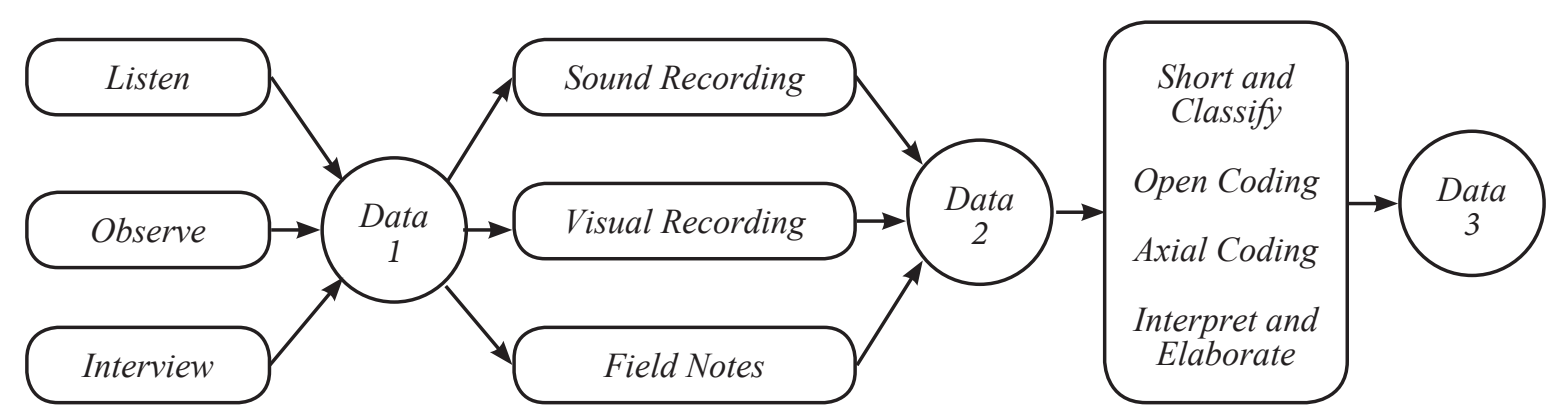

Gambar 3. Proses Analisis Data

Sumber: Ellen, 1984 (dalam Neuman, 2006: 468)

Keterangan gambar: Data 1 adalah data mentah dan pengalaman peneliti mengenai studi pendahuluan di Paguyuban Jamu Gendong Lestari, Data 2 adalah rekaman data hasil wawancara dan gambar, pengalaman dokumen fisik dan data hasil penelitian dan Data 3 adalah seleksi data, pemrosesan data, dan laporan hasil penelitian di Paguyuban Jamu Gendong Lestari.

\section{Pembangunan Sosial}

Kemiskinan merupakan masalah pembangunan kesejahteraan sosial yang berkaitan dengan berbagai bidang pembangunan lainnya seperti pengangguran, keterbelakangan, dan ketidakberdayaan. Kemiskinan merupakan masalah kompleks yang dihadapi oleh seluruh pemerintahan yang ada di dunia ini. Ia dipengaruhi oleh beberapa faktor antara lain tingkat pendapatan, pendidikan, kesehatan, akses barang dan jasa, lokasi geografis, gender, dan kondisi lingkungan. Kemiskinan sebagai masalah kesejahteraan sosial masih menjadi agenda besar pembangunan global dewasa ini, oleh Robert Chambers dalam Jolly (2010: 10) dikatakan bahwa dampak kemiskinan berpengaruh terhadap aspek-aspek kualitas hidup manusia yang mencakup:

“...material poverties, physical ill-being, insecurities, poverty of time, institutions and access, lack of information and political clout, legal and social inferiority, impacts on social relations etc." (Jolly: 2010)

Menurut Wirutomo (2013: 102), dalam upaya menyelamatkan peradaban manusia, konsep pembangunan perlu lebih ditopang oleh ilmu sosial-budaya guna mengimbangi dominasi ilmu-ilmu yang lebih berorientasi kebendaan.
Tantangannya, ilmu sosial-budaya tidak cukup melakukan pengkajian atau evaluasi capaian pembangunan (social impact assessment), yang bukan hanya analytical-evaluative, tetapi juga harus lebih prescriptive. Implikasinya, perlu perubahan pendekatan dari diubah dari sekadar the enlightenment model menjadi the engineering model. Hollnsteiner (dalam Tjokrowinoto,1995: 39) berpendapat perlunya model pembangunan yang mampu mempromosikan kekuatan manusia, bukan mengabdikan ketergantungan masyarakat miskin terhadap pemerintah.

Midgley (1995: 25-28) mendefinisikan pembangunan sosial sebagai suatu proses perubahan sosial yang terencana yang didesain untuk mengangkat kesejahteraan penduduk menyeluruh dengan proses pembangunan ekonomi yang dinamis. Artinya, pembangunan sebagai proses perubahan sosial yang direncanakan, untuk meningkatkan kesejahteraan masyarakat keseluruhan bersamaan dengan proses pembangunan ekonomi yang dinamis. Paradigma pembangunan sosial ini benarbenar mengubah total dari pembangunan yang berorientasi pertumbuhan menjadi berorientasi pada manusia (people centered development). Pembangunan sosial bukan hanya berfokus pada aspek sosial tetapi juga aspek ekonomi, di mana kesejahteraan masyarakat akan paling baik tercapai jika menghubungkan kesejahteraan sosial dan pembangunan ekonomi serta aspek lainnya (misalnya aspek lingkungan, budaya, politik).

Pembangunan Sosial memiliki 7 (tujuh) karakteristik (Midgley, 2005: 37-41) yaitu: Pertama, proses pembangunan manusia sangat terkait dengan pembangunan ekonomi secara inklusif dan berkelanjutan yang membawa 
kesejahteraan sosial bagi semua dan meningkatkan kemampuan masyarakat untuk berpartisipasi dalam ekonomi produktif untuk berkontribusi secara aktif dan positif. Kedua, pembangunan sosial memiliki fokus berbagai disiplin ilmu (interdisiplin) yang digunakan untuk menganalisa berbagai masalah sosial dan mengangkat kesejahteraan sosial. Ketiga, pembangunan sosial sebagai proses yang menekankan pada aspek yang ingin dirubah, proses perubahan itu sendiri dan tujuan pembangunan sosial tercapai. Keempat, proses pembangunan sosial bersifat progresif untuk mengangkat ide-ide untuk perbaikan kehidupan manusia dan peningkatan sosial ke arah lebih baik. Kelima, bersifat inventif di mana harus ada perencanaan dan strategi yang spesifik untuk pencapaian tujuan pembangunan sosial. Keenam, tujuan pembangunan sosial didukung oleh berbagai macam strategi untuk menghubungkan intervensi sosial dengan usahausaha pembangunan ekonomi. Terakhir, keenam, yaitu karakteristik ketujuh bahwa pembangunan sosial bersifat inklusif dan universal di mana bisa mencakup setiap level usaha untuk mengangkat kesejahteraan sosial mulai dari individu, masyarakat baik pedesaan, perkotaan, daerah dan lingkup suatu negara.

Pembangunan sosial dapat dilakukan dengan tiga strategi (Midgley, 2015: 149-201), yaitu:

1) Pembangunan sosial oleh individu, di mana kesejahteraan masyarakat secara keseluruhan dapat diangkat ketika para individu berusaha untuk mengangkat kesejahteraan mereka masing-masing. Pendekatannya lebih mengarah pada pendekatan individualis dan pendekatan enterprise (usaha).

2) Pembangunan sosial oleh masyarakat, di mana masyarakat saling bekerja sama secara harmonis serta memiliki tujuan yang sama untuk memenuhi kebutuhan mereka, memecahkan permasalahan mereka dan berusaha menciptakan kesempatan guna memperbaiki hidup. Pendekatannya lebih dikenal dengan nama pendekatan kemasyarakatan.

3) Pembangunan sosial oleh pemerintah, di mana pembangunan sosial dilakukan oleh pemerintah, dengan agen-agennya yang khusus, pembuatan kebijakan, para perencana dan administratornya. Negara mewakili kepentingan masyarakat secara keseluruhan dan memiliki tanggung jawab mengangkat kesejahteraan seluruh warga negaranya. Pendekatannya lebih dikenal dengan nama pendekatan statis/negara.

\section{Ekonomi Kreatif}

UNDP (2008, dalam Suparwoko, 2015: 2) mendefinisikan ekonomi kreatif sebagai bagian integratif dari pengetahuan yang bersifat inovatif, pemanfaatan teknologi secara kreatif, dan budaya. Sementara itu, dalam Instruksi Presiden Nomor 6 Tahun 2009 tentang Pengembangan Ekonomi Kreatif, ekonomi kreatif dijelaskan sebagai kegiatan ekonomi berdasarkan pada kreativitas, keterampilan, dan bakat individu untuk menciptakan daya kreasi dan daya cipta individu yang bernilai ekonomis dan berpengaruh pada kesejahteraan masyarakat Indonesia. Ekonomi kreatif merupakan sebuah konsep yang menempatkan kreativitas dan pengetahuan sebagai aset utama dalam menggerakkan ekonomi sebagai perwujudan nilai tambah dari suatu kekayaan intelektual yang lahir dari kreativitas manusia berbasis ilmu pengetahuan, warisan budaya, dan teknologi sehingga pertumbuhan ekonomi suatu negara diharapkan tidak lagi hanya mengandalkan sumber daya alam yang semakin terbatas.

Kementerian Pariwisata dan Ekonomi Kreatif (Kemenparekraf, 2014: 34) kemudian membuat model pengembangan ekonomi kreatif nasional di mana dalam upaya melakukan pengembangan industri kuliner di Indonesia, diperlukan pemetaan terhadap ekosistem kuliner yang terdiri dari rantai nilai kreatif, pasar, nurturance environment, dan pengarsipan. Aktor yang harus terlibat dalam ekosistem ini tidak terbatas pada model triple helix yaitu intelektual, pemerintah, dan bisnis, tetapi harus lebih luas dan melibatkan komunitas kreatif dan masyarakat konsumen karya kreatif. Keberhasilan ekonomi kreatif sangat tergantung kepada pendekatan pengembangan yang menyeluruh dan berkolaborasi dengan melibatkan seluruh pemangku kepentingan, sebagaimana diperlihatkan pada gambar berikut. 


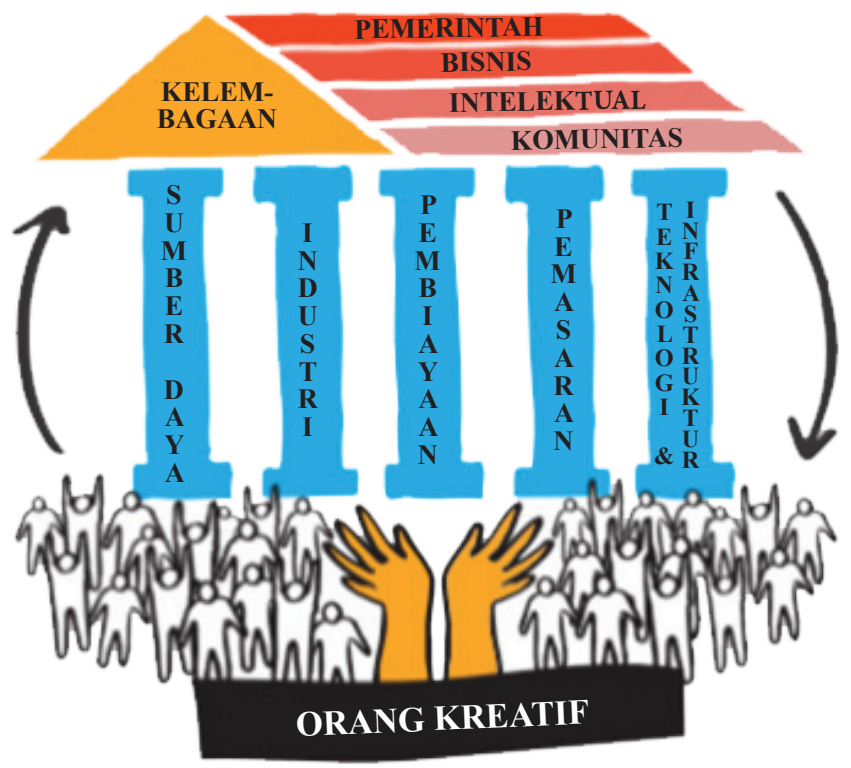

Gambar 4. Model Pengembangan Ekonomi Kreatif

Sumber: Kemenparekraf, 2014: 34

Dari Gambar 4 di atas, terdapat lima pilar pengembangan ekonomi kreatif yaitu, sumber daya kreatif berupa sumber daya alam dan sumber daya budaya, industri yang terdiri dari core creative industry (industri inti) dan backward and forward linkage creative industry, pembiayaan, teknologi dan infrastrastruktur, dan pemasaran. Pilar ini akan diperkuat oleh quad-helix melalui kelembagaan berupa norma, nilai, peraturan, dan perundangan hukum yang mengatur interaksi para aktor-aktor utama (intelektual, bisnis, komunitas, dan pemerintah) dalam pengembangan ekonomi kreatif. Kokohnya pondasi, kuatnya pilar, dan harmonisnya kelembagaan menjadi kunci pengembangan ekonomi kreatif.

\section{Hasil dan Pembahasan}

\section{Sejarah Paguyuban Jamu Gendong Lestari}

Paguyuban Jamu Gendong Lestari berlokasi di Kelurahan Kuningan Barat III RT 08/03 No. 39 Mampang Prapatan Jakarta Selatan. Berawal dari keinginan untuk mengubah nasib dan meningkatkan pendapatan ekonomi, $\mathrm{Bu}$ Lasmi wanita kelahiran Sukoharjo Jawa Tengah tahun 1970 mengajak sesama penjual jamu gendong yang bermukim di wilayah itu untuk mengesampingkan persaingan usaha dan memotivasi untuk membentuk kelompok paguyuban dan mengelola usaha jamu secara bersama-sama. "Bersatu Kita Teguh, Bercerai
Kita Runtuh," merupakan motto dari Paguyuban Jamu Gendong Lestari yang saat ini memiliki jumlah sebanyak 30 orang anggota yang semuanya berprofesi sebagai pedagang jamu gendong dan berasal dari Jawa yang pindah ke Jakarta untuk mengadu nasib. Sebelum ada wadah paguyuban, terdapat persaingan antara penjual jamu yang satu dengan yang lainnya. Meskipun pada dasarnya persaingan dalam bidang apapun adalah wajar, namun karena mereka menetap di satu kawasan, kesan miring itu dikhawatirkan akan mengganggu kehidupan sosial maupun kerukunan antar warga yang selama ini sudah terjalin.

Berikut adalah hasil temuan lapangan melalui wawancara dengan ketua paguyuban mengenai sejarah Berdirinya Paguyuban Jamu Gendong Lestari:

\begin{abstract}
"Awalnya itu tahun 1989 saya pindah ke Jakarta sini berjualan jamu, menetap di Kuningan Jakarta Selatan yang juga banyak ibu-ibu profesinya sama seperti saya dagang jamu gendong, sederetan rumah dari ujung ke ujung semua penghuninya adalah penjual jamu gendong dari Jawa Awalnya ya gitu-gitu aja jualan biasa, sampai kepingin rasanya ada kemajuan dari segi penghasilan dan saya koq mikir kalo sesama penjual jamu disini saling bahu membahu mengembangkan usaha jamu gendong sama-sama.. ya walaupun kan pada dasarnya wajar ya persaingan usaha, tapi saya berpikir daripada saling bersaing, kayaknya lebih baik bersama-sama untuk mencari perbaikan kondisi ekonomi dan saling menjaga kerukunan di daerah sini dan semakin memperkenalkan jamu gendong sebagai tradisi Indonesia khususnya Jawa. Saya mengumpulkan sekitar 30an sesama penjual jamu gendong dan membuat perkumpulan yang kami namakan paguyuban Jamu Gendong Lestari. Nama Lestari dipilih supaya usaha jamu gendong bisa lestari, awet menurun sampai ke anak cucu." (Wawancara dengan Lasmi, 26 Oktober 2018)
\end{abstract}

Perjuangan mereka dimulai dengan menyamakan visi-misi untuk meningkatkan taraf hidup dan mengesampingkan persaingan kemudian berkomitmen dalam memajukan usaha jamu gendong secara bersama-sama sebagai usaha kuliner jamu sebagai warisan budaya Indonesia. Keseriusan untuk maju juga diwujudkan pengurus dan anggota untuk aktif mengikuti serangkaian pameran, bazar hingga ke berbagai kota untuk meluaskan pemasaran dan mengikuti kontes 
jamu gendong yang diselenggarakan perusahaan jamu, hal ini tercermin dalam penjelasan yang dikemukakan oleh sekretaris paguyuban sebagai berikut:

"Berdirinya Paguyuban dimulai tahun 1989, waktu itu sepanjang rumah di daerah ini dari ujung ke ujung itu sama-sama penjual jamu gendong dan berasal dari daerah Jawa. Awalnya usaha gitu-gitu saja hasilnya boleh dibilang pas-pasan. Dari situ Bu Lasmi mengajak kita sesama penjual jamu gendong untuk membesarkan usaha jamu gendong bareng-bareng, dari meracik resepnya kita tes sama-sama supaya dapat racikan yang manteb. Bu Lasmi di antara kami adalah yang paling laku jualannya karena punya resep yang paling enak dan beliau tidak pelit mau bagi resep jamunya lalu kita racik sama-sama, kita bikin kesepakatan untuk titik-titik lokasi jualannya di mana saja supaya tidak ada yang bentrok jualan di lokasi yang sama, dibuat semacam jadwal hari ini siapa yang masak ngolah jamunya,siapa yang keliling lalu dibuat catatannya. Sejak awal saya dipercaya oleh kelompok sebagai sekretaris yang melakukan pencatatan dan hal-hal penting tentang kegiatan. Kami semakin dikenal itu sekitar tahun 2005 setelah aktif ikut bazar dan kontes jamu gendong, sebelumnya tahun 2001 $\mathrm{Bu}$ Lasmi menjuarai kontes jamu gendong yang diselenggarakan Martha Tilaar di Taman Mini. Waktu berjalan, kami semakin dikenal dan banyak pesanan jamu. Sejak 2005 itu penghasilan kami naik berlipat-lipat dan mulai banyak dinas kementerian dan perusahaan yang mengajak kami ikut pameran dan memesan jamu kami. Pada Tahun 2015 didorong oleh Martha Tilaar lewat Pak Heru koordinator CSR-nya mereka, akhirnya kami mengurus Badan Hukum Paguyuban Jamu Gendong Lestari sebagai bagian dari Laskar Jamu Gendong Indonesia melalui Akta Notaris Nomor 05 Tanggal 06 April 2015 dan disahkan oleh Kementerian Hukum Dan HAM Nomor AHU-0000593-AH.01.07 Tahun 2015 tanggal 24 April 2015. Tujuannya supaya kami menjadi organisasi yang formal dan profesional sehingga saat ada pihak yang mengajak kami kerja sama misalnya ada pemesanan dalam jumlah besar atau pameran-pameran besar sudah terpenuhi persyaratan dokumen administrasi yang biasanya dibutuhkan untuk kerja sama. Sejak saat itu usaha kami semakin berkembang banyak pesanan dan kerja sama misalnya dari Kementerian Kesehatan, Kementerian Pertanian, Badan POM, Kantor Sekretariat Presiden, dan Kementerian Perdagangan. Kami juga telah menerima banyak bantuan seperti sepeda, bakul, botol kaca, blender, dan kompor gas lalu kami bagikan ke anggota tidak hanya di Paguyuban Jamu Gendong Lestari tapi juga diberikan ke luar kelompok di bawah Laskar Jamu Gendong Indonesia." (Wawancara dengan Purwanti, 26 Oktober 2018)

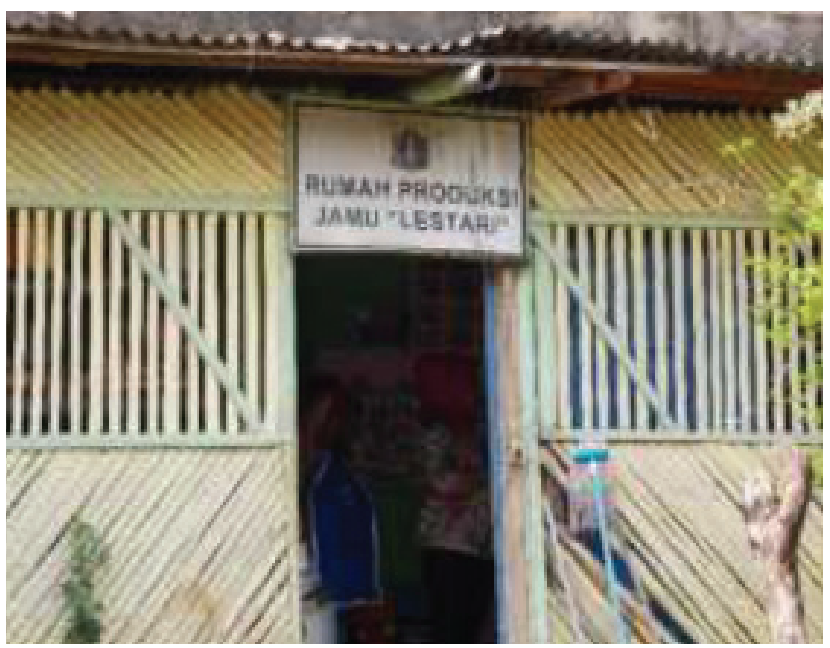

\section{Gambar 5. Rumah Produksi Jamu Paguyuban Jamu Gendong Lestari}

Sumber: Arsip foto Paguyuban Jamu Gendong Lestari, 2018

Struktur kepengurusan Paguyuban Jamu Gendong Lestari yaitu ketua, sekretaris dan bendahara, selebihnya adalah anggota. Keseluruhan anggota paguyuban berjumlah 30 (tiga puluh) orang. Struktur dibuat sesederhana mungkin untuk menjalankan fungsi dan peran seperti ketua untuk mengarahkan dan mengingatkan komitmen akan tujuan, bendahara mengurusi urusan keuangan, dan sekretaris mengurusi jadwal dan pencatatan. Sementara proses pengambilan keputusan, pembagian tugas termasuk pergantian kepengurusan tergantung kesepakatan di antara seluruh anggota lewat pertemuan rutin Kamis sore. Proses komunikasi dan interaksi dilaksanakan secara musyawarah dan kekeluargaan. Dalam menjalankan pengelolaan usaha jamu, ditetapkan aturan main yang disepakati bersama. Hasil temuan lapangan berdasarkan wawancara dengan pengurus Paguyuban Jamu Gendong Lestari mengenai aturan main yang ditetapkan sebagai berikut:

"Aturan mainnya misalnya soal harga jamu itu kita buat seragam, kita mengolahnya di rumah produksi di sini, kemudian ada sistem jadwal keliling dan bagian produksi dan pembagian hasil. Jadi dari semua hasil penjualan dikurangi 
biaya produksi untuk muter usaha, sisanya keuntungan kita sisihkan ke uang kas yang dipakai untuk pengembangan produk, kegiatan yang mau kita lakukan dan untuk dana sosial misalnya untuk dikeluarkan jika ada yang sakit, hajatan, atau melahirkan." (Wawancara dengan Lasmi, 26 Oktober 2018)

"Yang penting ya itu tadi tidak boleh menggunakan bahan kimia obat walau ada pihak luar yang kasih tau kalau bisa lebih awet tambah benzoat, tapi kami harus dan komitmen menjaga kualitas dan kepercayaan pelanggan. Kemudian soal pendapatan karena saya dipercaya menjadi bendahara jadi setiap usaha ada pencatatannya, dan ada sebagian uang yang disisihkan dari keuntungan usaha dikumpulkan menjadi uang kas yang digunakan untuk kegiatan paguyuban dan uang sosial, misalnya dikeluarkan jika ada anggota atau keluarganya yang sakit, ada hajatan, melahirkan, kematian. Itu semua ada pencatatannya dan setiap pertemuan dilaporkan. Lalu misalnya mau ada hari raya lebaran itu dibagikan THR yang uangnya itu tadi diatur dan disepakati bersama dan dikelola untuk kesejahteraan bersama." (Wawancara dengan Desi, 26 Oktober 2018)

"Aturan main tentunya hasil dari kesepakatan bersama, yang paling utama itu kita sepakat untuk memakai bahan-bahan berkualitas dan semua harus taat untuk tidak pakai bahan kimia obat seperti natrium benzoat, karena itu nggak bagus untuk kesehatan walaupun jamu jadi awet berhari-hari tapi kami tidak menggunakannya karena komitmen terhadap kepercayaan pelanggan apalagi kami sudah tersertifikasi oleh Badan Pom dan punya izin usaha yang secara berkala pasti akan dicek betul oleh petugasnya. Jadi kami mau usaha yang jujur, amanah dan sehat karena langganan dan pesanan sudah banyak apalagi juga dinikmati mulai dari anakanak sampai lansia jadi kami jaga betul kualitas produk jamu kami." (Wawancara dengan Purwanti, 26 Oktober 2018)

Lebih lanjut mengenai aturan main diperlihatkan dalam temuan lapangan berdasarkan wawancara mendalam secara berkelompok dengan anggota Paguyuban Jamu Gendong Lestari sebagai berikut:

"Aturan main mengikuti kesepakatan yang dibuat dan diputuskan sesuai pertemuan rutin Kamis sore, membayar iuran mingguan dan tabungan anggota, mengikuti pembuatan jamu sesuai resep dan tidak boleh memakai bahan kimia obat, semua bahan jamu harus alami dari rempahrempah segar dan berkualitas." (Wawancara dengan Supini, 2 November 2018)

"Oh iya ada, kami juga harus komitmen mengikuti jadwal keliling jamu sesuai kesepakatan, kalaupun misal berhalangan ada kepentingan mendesak bisa minta tuker jadwal apakah mau keliling atau standby mengolah jamu, yang penting ada kabar supaya tidak mengganggu produksi." (Wawancara dengan Ita, 2 November 2018).

"Saya menambahkan terkait kewajiban menyetor iuran sebetulnya itu nanti manfaatnya kembali kepada kami, ada iuran sosial dan dua jenis tabungan yang pertama bisa diambil kapan saja kalau ada urusan mendesak, yang tabungan satu lagi hanya boleh diambil setahun sekali pas lebaran, tujuannya biar hasilnya kelihatan karena nggak diutik-utik gitu." (Wawancara dengan Mulyati, 2 November 2018).

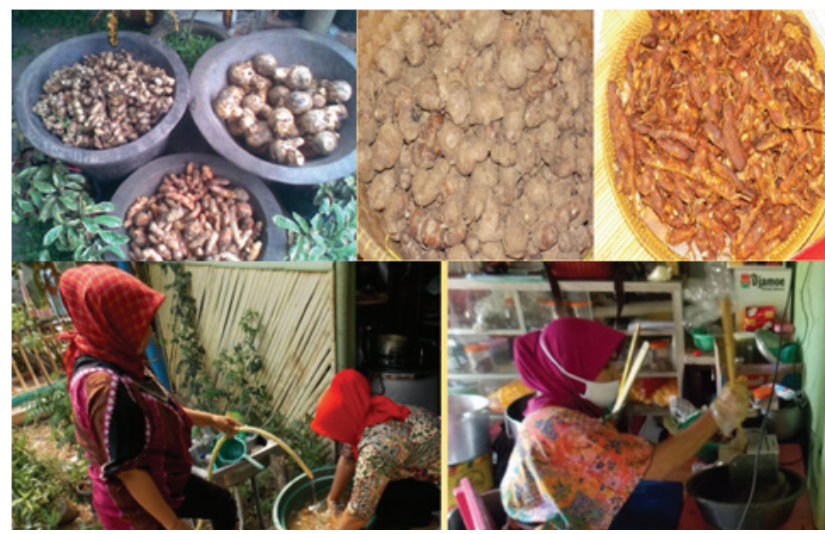

Gambar 6. Proses Pengolahan Jamu

Sumber: Arsip foto Paguyuban Jamu Gendong Lestari, 2018

Melalui serangkaian usaha, kemauan, kerja keras yang dilakukan Paguyuban Jamu Gendong Lestari dalam mengembangkan programnya, kini komunitas tersebut telah menunjukan keberhasilan-keberhasilan di antaranya:

Perbaikan dan peningkatan kesejahteraan anggota;(2) Mengembangkan inovasi produk agar tampak berbeda dengan penjual jamu gendong lainnya. Selain jamu siap saji, Paguyuban Jamu Gendong Lestari kini juga membuat sejumlah varian jamu bubuk dalam kemasan yang mampu bertahan bulanan, di antaranya jamu beras kencur, jamu kunyit asam, jamu temulawak, jamu 
instan, wedang jahe dan wedang sereh. Kendati berkelas usaha rumahan, produk ini sudah dapat mengantongi sertifikat produksi industri rumah tangga (PIRT) dan sertifikasi Badan POM untuk Jamu Bebas Bahan Kimia Obat dan Pengawet; (3) Apresiasi dari berbagai instansi baik Pemerintah maupun swasta di antaranya bantuan sepeda dari Kementerian Perdagangan; (4) Menjadi langganan setia beberapa instansi pemerintah dan swasta juga kerap memesan jamu Lestari untuk disajikan sebagai minuman saat penyelenggaraan acara kenegaraan yang diselenggarakan Badan Ekonomi Kreatif, Kementerian Pariwisata, Pemerintah Provinsi DKI Jakarta dan Sekretariat Negara dan juga acara-acara yang diselenggarakan oleh pihak swasta seperti Martha Tilaar dan Sido Muncul; (5) Paguyuban Jamu Gendong Lestari juga mendapat serangkaian penghargaan di antaranya Penghargaan Komunitas Inspirasi Tupperware She Can, Salimah Award, Penghargaan Komunitas Wanita dari Trubus Bina Swadaya.

Selain bergerak dalam usaha produksi sampai dengan pemasaran jamu, Paguyuban Jamu Gendong Lestari berhasil mengembangkan kapasitasnya yaitu diundang untuk memberikan pelatihan usaha membuat racikan jamu gendong kepada masyarakat. Semakin banyaknya pelanggan dan pesanan membuat mobilitas penjualan juga tinggi, kini sebagian penjual jamu gendong tak lagi menggendong bakul tapi sudah berganti sepeda hasil dari bantuan Kementerian Perdagangan.

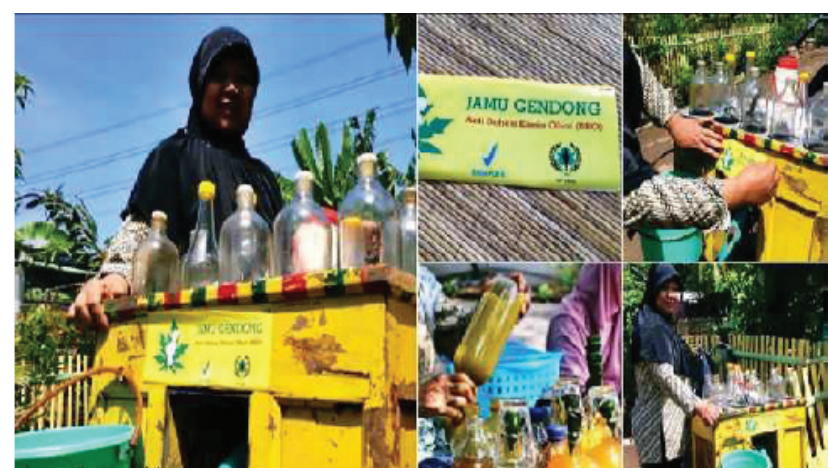

Gambar 7. Sepeda yang Ditempel Stiker Jamu Bebas Bahan Kimia Obat dari BPOM

Sumber: Arsip foto Paguyuban Jamu Gendong Lestari, 2018

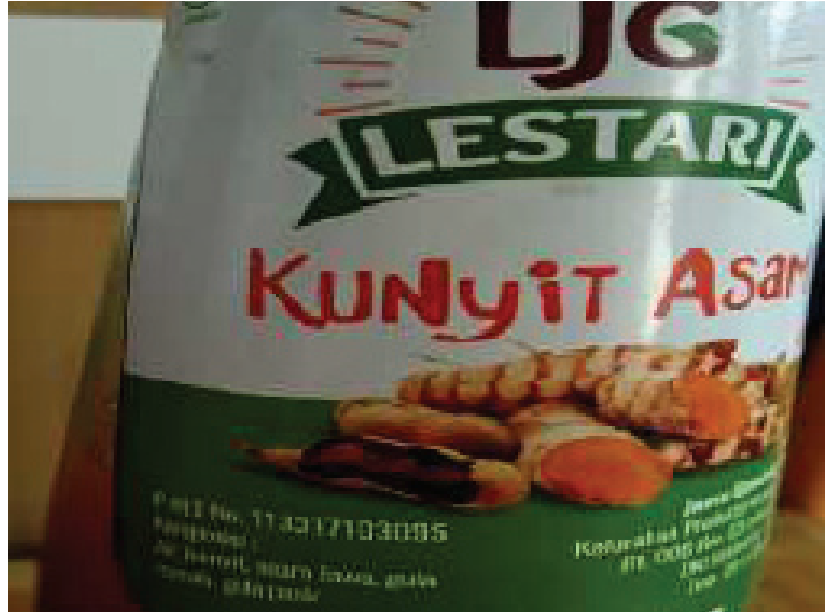

Gambar 8. Izin P-IRT pada Stiker Kemasan Jamu yang Diproduksi Paguyuban Jamu Gendong Lestari

Sumber: Dokumentasi Penelitian, 2018

\section{Pembangunan Sosial melalui Sektor Ekonomi Kreatif oleh Paguyuban Jamu Gendong Lestari}

Paguyuban Jamu Gendong Lestari merupakan salah satu potret komunitas kreatif yang berkembang di DKI Jakarta yang menggeluti subsektor kuliner berbasis budaya dan kearifan lokal yaitu jamu. Komunitas ini telah berhasil melakukan pembangunan sosial oleh masyarakat yang dibentuk oleh masyarakat secara mandiri dan aktif untuk mengembangkan kapasitasnya dalam rangka meningkatkan kesejahteraan para anggotanya. Langkah-langkah yang dilakukan oleh Paguyuban Jamu Gendong Lestari menunjukan apa yang telah dituangkan dalam model pengembangan ekonomi kreatif nasional oleh Kemenparekraf.

Berdasarkan model pengembangan ekonomi kreatif Kemenparekraf, peneliti dapat mengidentifikasikan Paguyuban Jamu Gendong Lestari sebagai aktor atau pelaku ekonomi kreatif menjalankan pilar-pilar pengembangan ekonomi kreatif: sumber dayanya adalah anggota paguyuban yang berprofesi sebagai penjual jamu gendong yang melakukan pengelolaan sumber daya budaya berupa jamu sebagai salah satu minuman yang menjadi produk kuliner berwawasan budaya. Pilar pembiayaan, teknologi dan infrastruktur, serta pemasaran dilaksanakan oleh Paguyuban Jamu Gendong Lestari secara aktif mandiri dengan terus mengembangkan 
inovasi dan kreativitas sebagai pelaku industri kuliner berbasis komunitas dalam menyediakan pilihan jamu untuk melengkapi gaya hidup sehat bagi para penikmatnya, sehingga dapat dipahami bahwa pembangunan sosial merupakan sebuah pendekatan yang bertujuan untuk mensejahterakan masyarakat melalui perpaduan antara pembangunan ekonomi dan sosial secara paralel.

Pada penelitian ini diketahui bahwa proses pembangunan sosial yang dilakukan yaitu dengan mengajak warga yang rata-rata berprofesi sebagai pedagang jamu untuk mengelola usaha jamu gendong dengan membentuk wadah yang dinamakan Paguyuban Jamu Gendong Lestari pada tahun 1989. Sebelum ada paguyuban, terdapat persaingan antara sesama penjual jamu meskipun pada dasarnya persaingan dalam bidang apapun adalah wajar, namun kondisi ini yang akan diubah dengan memilih untuk bersatu dalam suatu wadah dan saling memotivasi untuk kompak dan bangkit demi meningkatkan kesejahteraan hidup yang lebih baik serta menjaga kerukunan antara warga dengan tidak bersaing usaha jamu satu sama lain melainkan memilih untuk bersama-sama mengelola usaha jamu gendong.

Proses pembangunan sosial yang dilakukan oleh Paguyuban Jamu Gendong Lestari dimulai dengan berkumpul bersama dalam musyawarah untuk mengidentifikasi dan merencanakan halhal apa saja yang akan dilakukan. "Bersatu Kita Teguh, Bercerai Kita Runtuh," merupakan motto yang diambil sebagai motivasi akan pentingnya kekompakan dan kepedulian bersama untuk bangkit demi mencapai taraf hidup yang bermanfaat kemudian menyamakan visi dan misi untuk mengesampingkan persaingan kemudian berkomitmen untuk mengelola dan memajukan usaha jamu secara bersama-sama.

Keseriusan dimulai dengan membentuk pengurus, mengadakan pertemuan rutin setiap sore untuk membuat standar resep jamu yang sama, membuat mekanisme iuran dari para anggota supaya ada uang kas untuk biaya operasional paguyuban yang digunakan untuk mengurus izin usaha P-IRT ke Dinas Perindustrian dan Perdagangan DKI Jakarta serta sertifikasi jamu tanpa bahan kimia obat ke Badan POM.
Untuk menambah uang operasional, para pengurus dan anggota rajin mengikuti kontes jamu gendong yang diselenggarakan oleh Perusahaan Jamu seperti Sido Muncul dan Martha Tilaar dan hadiahnya digunakan untuk memajukan pengelolaan usaha jamu. Keseriusan semakin diperlihatkan dengan aktif mengikuti pameran dan bazaar ke berbagai kota untuk meluaskan pemasaran dan membuat inovasi varian produk jamu yang baru seperti sanapis (sawi, nanas, jeruk nipis) dan selemanis (sereh lemon dan kayu manis) yang digemari oleh banyak kalangan hingga diterima oleh kementerian dan presiden dari zaman Soeharto sampai Joko Widodo.

Kegiatan pengelolaan usaha jamu yang dilakukan Paguyuban Jamu Gendong Lestari menunjukan perubahan di mana tujuan dari pembangunan sosial yang ditetapkan paguyuban tercapai. Secara ekonomi, dari hasil penelitian didapat informasi dari para anggota paguyuban bahwa setiap minggunya para anggota mampu membawa penghasilan bersih berkisar antara Rp1.000.000 sampai Rp1.500.000 yang digunakan untuk perbaikan taraf hidup keluarga masing-masing dan bisa mewujudkan kondisi yang lebih sejahtera, dan ada dana sosial yang diberikan saat ada anggota yang sakit, melahirkan, kena musibah atau mengadakan hajatan dan ada dua jenis tabungan yang satu bisa diambil kapan saja dan yang satu lagi untuk tabungan hari raya.

Berikut uraian mengenai ilustrasi pendapatan anggota yang diperoleh melalui wawancara mendalam dan observasi dengan bendahara paguyuban. Pembagian hasil usaha telah disepakati oleh seluruh anggota melalui proses musyawarah. Hasil pendapatan jika dihitung rata-rata adalah sebagai berikut: hasil berjualan keliling didapat rata-rata $\mathrm{Rp} 750.000$, jika 20 orang keliling maka omset Rp4.500.00 per hari dikalikan enam kali keliling dalam seminggu, total omset Rp90.000.000. Pembagian modal dan keuntungan 50:50 di mana didapat keuntungan Rp45.000.000. Hasil pesanan instansi tiap minggunya rata-rata mendapat keuntungan Rp3.000.000, sehingga total keuntungan yang didapat tiap minggu adalah Rp48.000.000 kemudian dibagi rata sejumlah anggota yaitu 30 orang (10 orang menangani produksi, 20 orang bertugas jualan keliling sesuai jadwal yang telah 
disepakati). Setiap minggu tiap anggota mendapat hasil Rp1.600.000 dikurangi Rp300.000 dengan perincian Rp50.000 untuk dana sosial, Rp200.000 untuk tabungan THR yang hanya boleh diambil setahun sekali dan Rp50.000 untuk tabungan rutin yang bisa diambil kapan saja oleh anggota jika ada kebutuhan mendesak, sehingga jumlah bersih yang dibawa pulang setiap anggota setiap minggunya adalah Rp1.300.000, sebagaimana gambar yang didapat dari hasil observasi di bawah ini:

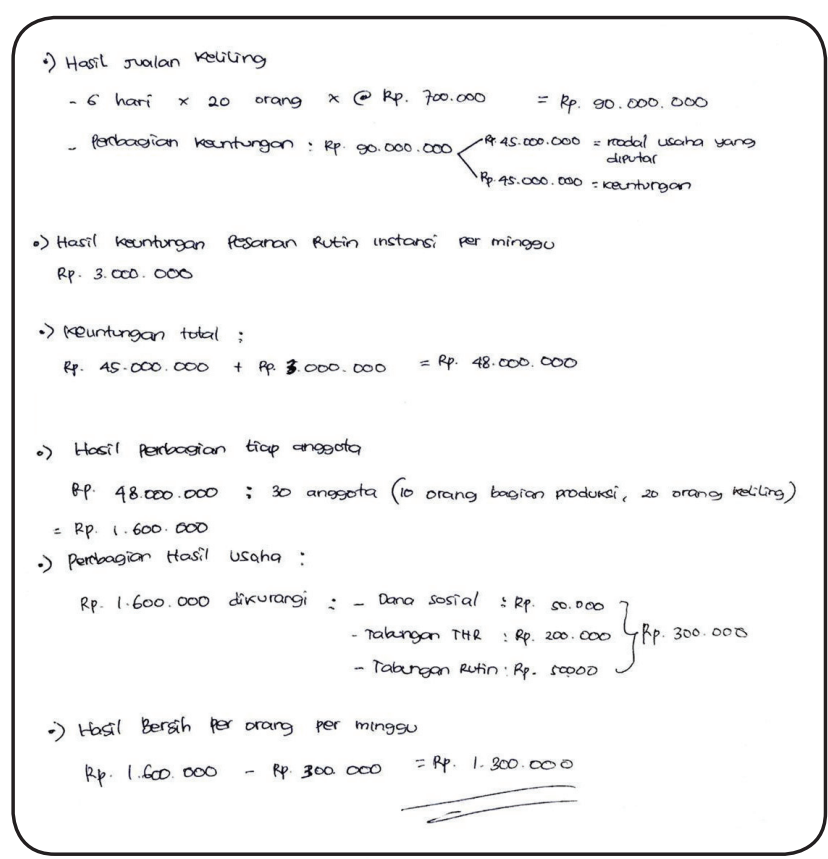

\section{Gambar 9. Ilustrasi Pembagian Hasil Usaha Paguyuban Jamu Gendong Lestari Sumber: Dokumentasi Penelitian, 2018}

Keuntungan dari faktor ekonomi ini membuat Paguyuban Jamu Gendong Lestari tetap bertahan dikarenakan kesejahteraan anggota kelompok terjamin dan membuat Paguyuban Jamu Gendong Lestari mampu bertahan selama hampir 30 (tiga puluh) tahun sejak didirikan pada tahun 1989.

Selanjutnya penjelasan mengenai aspek pembangunan sosial diperlihatkan dari hasil penelitian yang menunjukan bahwa kegiatan yang dilakukan Paguyuban Jamu Gendong Lestari tidak hanya bersifat ekonomi tetapi juga bersifat sosial di mana mereka juga aktif berpartisipasi dalam kegiatan sosial kemasyarakatan di lingkungan mereka tinggal seperti kegiatan pemberian jamu pada program Posyandu Balita dan Posbindu Lansia, Kegiatan menanam tanaman Toga untuk penghijauan melalui kelompok Gapoktan, dan kegiatan keagamaan seperti pengajian ibu-ibu.

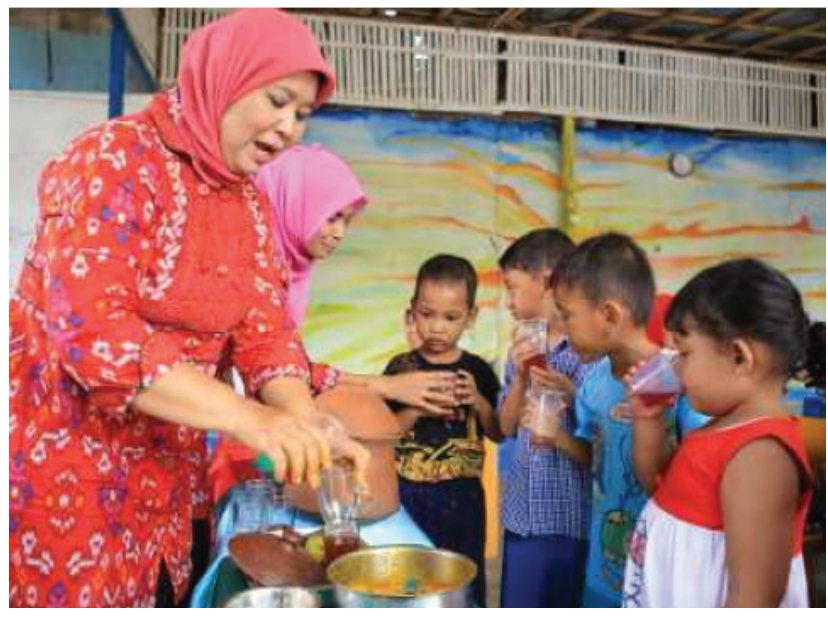

Gambar 14. Pemberian Jamu Kepada AnakAnak dalam Kegiatan Posyandu RT 08/03 Sumber: Arsip Foto Paguyuban Jamu Gendong Lestari, 2018

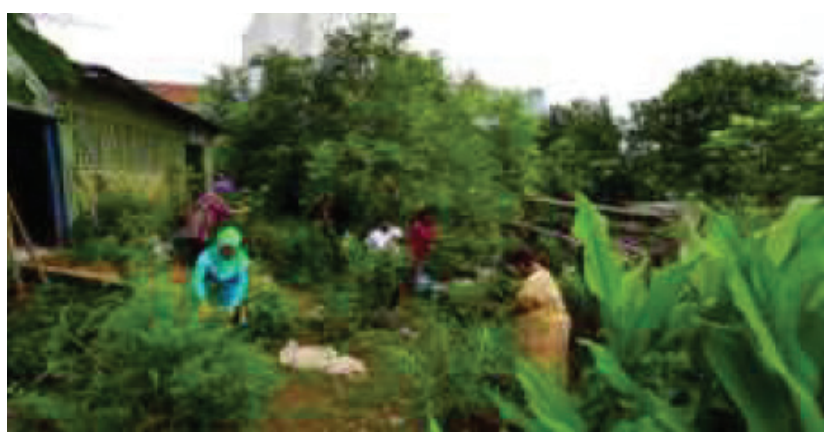

Gambar 15. Kegiatan Menanam Tanaman Toga di Lingkungan RT 08/03

Sumber: Arsip Foto Paguyuban Jamu Gendong Lestari, 2018

\section{Penutup}

Serangkaian usaha yang dilakukan Paguyuban Jamu Gendong Lestari membuktikan suatu perspektif tentang perubahan sosial dan ekonomi yang direncanakan, dibina, dikembangkan yang didalamnya menyangkut inovasi-inovasi yang menyiratkan perubahan secara terencana terhadap nilai, pola yang diyakini dan dijalankan penuh komitmen untuk membawa jamu gendong naik level dan dikelola secara baik, sehat dan profesional walaupun dibangun dan dikerjakan melalui manajemen yang tradisional dan bercirikan kekeluargaan dan gotong royong, namun cara ini berhasil membuat usaha mereka maju, membawa perubahan baik secara peningkatan ekonomi dan memberikan manfaat secara sosial bagi warga sekitar. 
Berangkat dari kebutuhan komunitas dan persamaan nasib sesama penjual jamu gendong kemudian memutuskan untuk mengelola secara bersama di bawah kepemimpinan yang tepat dan kemudian berkembang menjadi kebutuhan warga, ditangkap oleh banyak lembaga baik pihak swasta maupun instansi pemerintah, kemudian mampu mewujudkan pembangunan sosial oleh masyarakat sebagai salah satu strategi dalam pembangunan sosial karena keberadaan Paguyuban Jamu Gendong Lestari membawa perubahan baik secara ekonomi maupun perubahan secara sosial.

Berdasarkan hasil penelitian yang telah dijabarkan di atas dan sejalan dengan tujuan dari artikel ini, maka dapat disimpulkan bahwa proses pembangunan sosial yang dilaksanakan oleh Paguyuban Jamu Gendong Lestari memenuhi tujuh karakteristik dari pembangunan sosial yaitu:

1) Melalui pengelolaan usaha jamu gendong yang telah dibangun sejak tahun 1989, Paguyuban Jamu Gendong Lestari berhasil mewujudkan pembangunan ekonomi yang inklusif dan berkelanjutan yang membawa kesejahteraan masyarakat yang menjadi anggotanya untuk berpartisipasi merintis usaha jamu gendong secara aktif dan positif.

2) Melalui semboyan "bersatu kita teguh, bercerai kita runtuh", menjawab masalah sosial diantara sesama penjual jamu gendong untuk menghindari persaingan dan sepakat untuk membentuk paguyuban dan mengelola usaha jamu secara bersama-sama.

3) Paguyuban Jamu Gendong Lestari berhasil mewujudkan proses pembangunan sosial yang menekankan pada perubahan untuk mewujudkan keberhasilan secara ekonomi dengan meningkatkan pendapatan dan mewujudkan kondisi sosial yang rukun antar sesama anggota serta dengan adanya paguyuban dapat berkontribusi terhadap lingkungan sekitar melalui program pemberian jamu untuk anak-anak dan lansia serta menanam tanaman TOGA untuk penghijauan yang dapat digunakan sebagai bahan pembuat jamu.

4) Ide untuk mewujudkan perbaikan hidup dan peningkatan sosial ke arah yang lebih baik ditempuh oleh seluruh anggota Paguyuban Jamu Gendong Lestari melalui pengelolaan usaha jamu gendong yang bersifat gotong royong dan kekeluargaan dan komitmen yang tinggi untuk menjalani kesepakatan usaha yang telah dibuat bersama-sama.

5) Dalam mewujudkan usaha jamu kearah yang lebih baik, Paguyuban Jamu Gendong Lestari menetapkan rencana dan menjalankan pengelolaan jamu melalui strategi pembagian tugas melalui musyawarah seluruh anggota lewat pertemuan rutin yang diselenggarakan setiap Kamis sore.

6) Strategi yang dijalankan Paguyuban Jamu Gendong Lestari adalah dengan mengangkat jamu sebagai warisan budaya dan mengelolanya dengan serius serta mempromosikan lewat Bazzar agar kamu dapat semakin dikenal dan diterima oleh masyarakat luas.

7) Paguyuban Jamu Gendong Lestari merupakan potret komunitas para penjual jamu gendong yang berhasil mengangkat kesejahteraan tiap anggotanya dan juga bermanfaat bagi lingkungan sekitar tempat paguyuban tersebut berdiri dan berkembang.

Lebih lanjut dapat dijelaskan bahwa strategi pembangunan sosial yang dijalankan Paguyuban Jamu Gendong Lestari adalah strategi pembangunan sosial oleh masyarakat, di mana bentuk paguyuban dapat menjadi wadah bagi masyarakat yang menjadi anggota saling bekerja sama secara harmonis untuk memenuhi kebutuhan mereka, memecahkan masalah mereka secara aktif dan mandiri dan berupaya menciptakan kesempatan guna memperbaiki hidup melalui pengelolaan usaha jamu gendong. Kemudian, dari temuan penelitian yang telah diuraikan di atas, menunjukkan bahwa Paguyuban Jamu Gendong Lestari membantu masyarakat untuk dapat mengambil peluang di sektor ekonomi kreatif sebagai sektor yang berfokus pada pembangunan sosial di mana kebijakan pemerintah diarahkan kepada pembangunan inklusif yang memberikan kesempatan yang seluas-luasnya kepada seluruh masyarakat untuk mengambil bagian dalam kegiatan ekonomi yang mendorong dan membantu pengembangan potensi ekonomi kreatiflokal melalui jamu yang melibatkan dan meletakan masyarakat sebagai pelaku penting 
untuk mengangkat pembangunan sosial pada tingkat lokal.

Berdasarkan pembahasan dan kesimpulan dalam artikel ini maka saran yang dapat disampaikan adalah sebagai berikut:

1) Kepada Pengurus Paguyuban Jamu Gendong Lestari, berdasarkan hasil penelitian bahwa sejak awal berdiri hingga saat ini tokoh yang sama masih dipercaya menjadi pemimpin, perlu adanya pemikiran untuk membuat mekanisme pergantian kepemimpinan sebagai bentuk untuk menghindari dominasi ketokohan dan sebagai proses pembelajaran untuk anggota yang lain.

2) Kepada, Pemerintah Pusat dalam hal ini Kementerian Pariwisata dan Ekonomi Kreatif dan Kementerian Perdagangan agar membuat pemetaan terhadap keberadaan kelembagaan lokal yang berbasis kelompok atau komunitas pada sektor ekonomi kreatif, karena bila mau dicari dan diteliti lebih banyak, model kelembagaan lokal seperti Paguyuban Jamu Gendong Lestari banyak ditemukan di daerah lain sehingga pada saat melakukan kebijakan membuat program dan kegiatan sudah mulai menggeser paradigma untuk tidak membuat kelompok baru yang sifatnya top down tetapi memanfaatkan kelembagaan lokal yang sudah eksis dan punya andil positif dalam programprogram pembangunan sosial.

3) Kepada Dewan Perwakilan Rakyat sebagai unsur legislatif, agar semakin berkolaborasi dengan Pemerintah untuk membangun mekanisme kelembagaan berupa peraturan perundangan yang mendorong ekosistem ekonomi kreatif yang mengarahkan pada pembangunan inklusif yang memberikan kesempatan seluas-luasnya kepada seluruh masyarakat untuk mengambil bagian dalam kegiatan ekonomi kreatif dan memposisikan masyarakat sebagai pelaku penting pada sektor ini.

\section{Ucapan Terima Kasih}

Terima kasih kepada Pengurus dan anggota Paguyuban Jamu Gendong Lestari, Ketua RT 08/03 Kelurahan Kuningan Barat Kecamatan Mampang Prapatan Jakarta Selatan atas kerja sama selama penelitian ini berlangsung.

\section{Daftar Pustaka}

Alston, M., Bowles, W. (1998). Research For Social Worker, An Introduction to Methods. Sidney: Allen and Unwin.

Agung, A. A. G. (2015). Pengembangan Model Wisata Edukasi-Ekonomi Berbasis Industri Kreatif Berwawasan Kearifan Lokal Untuk meningkatkan Ekonomi Masyarakat Di Bali. Jurnal Imu Sosial dan Humaniora, Universitas Pendidikan Ganesha, 4(2), 585-597. ISSN: 23032898. doi: 10.23887/jish-undiksha.v4i2.6380

Bekraf dan BPS. (2017). Data Statistik dan Hasil Survei Ekonomi Kreatif tahun 2016. Jakarta: Badan Ekonomi Kreatif dan Badan Pusat Statistik. Retrieved from https://www.bekraf. go.id/pustaka/page/data-statistik-dan-hasilsurvei-ekonomi-kreatif, on 6 Desember 2019.

BPS. (2018). Press Release Persentase Penduduk Miskin Maret 2018 Turun Menjadi 9,82 Persen. Jakarta: Badan Pusat Statistik. Retrieved from https://bps.go.id/pressrelease/2018/07/16/1483/ persentase-penduduk-miskin-maret-2018-turunmenjadi-9-82-persen.html, on 6 Desember 2019.

Citra, I.P.A. (2017). Strategi Pemberdayaan Masyarakat Untuk Pengembangan Ekowisata Wilayah Pesisir di Kabupaten Buleleng. Jurnal Ilmu Sosial dan Humaniora, 6(1), 31-41. Retrieved from https://ejournal.undiksha.ac.id/ index.php/JISH/article/view/8484/6332.

Creswell, J. W. (1998). Qualitative inquiry and research design: Choosing among five designs. Thousand Oaks, CA: Sage.

Instruksi Presiden Nomor 6 Tahun 2009 Tentang Pengembangan Ekonomi Kreatif. Jakarta: Badan Ekonomi Kreatif.

Jolly, S. (2010). Poverty and sexuality: What are the connections?. Swedish International Development Cooperation Agency. Retrieved from https://www.eldis.org/document/A61881, on 6 Desember 2019.

Kartika, N. (2013). Pemberdayaan Usaha Mikro berbasis Jamu Sebagai Bentuk Ketahanan Ekonomi Masyarakat (Makalah). Seminar Nasional Fakultas Ekonomi Universitas Tarumanegara "Optimisme Ekonomi Indonesia 2013, Antara Peluang dan Tantangan". Retrieved from http://repository.ut.ac.id/5084/, on 6 Desember 2019. 
Kementerian Pariwisata dan Ekonomi Kreatif. (2014). Proyeksi Penerimaan Devisa Dari Sektor-Sektor Utama Dalam Perekonomian Indonesia. Jakarta: Pusdatin Kemenparekraf. Disampaikan dalam Rapat Penyusunan Laporan Akuntabilitas dan Kinerja Instansi Pemerintah Kementerian Pariwisata Dan Ekonomi Kreatif Tahun 2015.

Kementerian Pariwisata dan Ekonomi Kreatif. (2015). Ekonomi Kreatif Kekuatan Baru Ekonomi Indonesia 2025. Jakarta: Kemenparekraf.

Midgley, J. (1995). Social Development: The Developmental Perspective In Social Welfare. London: SAGE Publication Ltd.

Midgley, J. (2005). Pembangunan Sosial Perspektif Pembangunan Dalam Kesejahteraan Sosial. (Dorita Setiawan dan Sirojudin Abbas, Penerjemah). Jakarta: Diperta Islam Departemen Agama Republik Indonesia.

Neuman, W.L. (2006). Social Research Methods (Qualitative and Quantitative Approaches). Fourth Edition. USA: Allyn and Bacon.

Patria, A. S dan Mutmainah, S. (2018). Model Pemberdayaan Kelompok Lanjut Usia Wanita Melalui Industri Kreatif. Jurnal Pengabdian Kepada Masyarakat, Universitas Negeri Surabaya, 9(2), 15-27, ISSN: 2087-3565. Retrieved from http://journal.upgris.ac.id/index. php/e-dimas/article/view/2019, on 6 Desember 2019.

Pemprov DKI Jakarta. (2018). Dokumen Rencana Kerja Pemerintah Daerah Tahun 2018. Jakarta: Bappeda Provinsi DKI Jakarta.

Ditjen PP Kemenkumham. (2015). Peraturan Presiden tentang Badan Ekonomi Kreatif (Peraturan Presiden Republik Indonesia Nomor 72 Tahun 2015 tentang Perubahan Atas Peraturan Presiden Nomor 6 Tahun 2015 Tentang Badan Ekonomi Kreatif). Retrieved from http://ditjenpp. kemenkumham.go.id/arsip/ln/2015/ps72-2015. pdf, on 6 Desember 2019.

Peraturan Presiden Republik Indonesia Nomor 59 Tahun 2017 tentang Pelaksanaan Pencapaian Tujuan Berkelanjutan.

Rakib, M. (2017). Strategi Pengembangan Ekonomi Kreatif Berbasis Kearifan Lokal Sebagai Penunjang Daya Tarik Wisata. Jurnal Kepariwisataan. Politeknik Pariwisata Makassar, 1(2), 54-69.
Tjokrowinoto. (1995). Politik Pembangunan: Sebuah Analisis Konsep, Arah dan Strategi. Yogyakarta: Tiara Wacana

United Nations. (2015). Transforming Our World: the 2030 Agenda for Sustainable Development. Retrieved from https://sustainabledevelopment. un.org/, on 6 Desember 2019.

Wirutomo, P. (2013). Mencari Makna Pembangunan Sosial: Studi Kasus Sektor Informal di Solo. Jurnal Sosiologi, 18(1), 101-120.

Yusuf A.H. dan Nimasari, E.P. (2018). Model Program Pemberdayaan Masyarakat Desa Berbasis Komunitas. ARISTO. 6(1), 45-67. Retrieved from http://journal.umpo.ac.id/index. php/aristo/article/view/778, on 6 Desember 2019. doi: 10.24269/ars.v6i1.778

Yulinda, I.P. (2017). Pemberdayaan Ekonomi Kreatif Masyarakat Melalui Kerajinan Batik, Studi Kasus: Kampoeng Batik Palbatu Tebet, Jakarta Selatan (Skripsi). Universitas Negeri Jakarta. 